\title{
DOI: 10.7596/taksad.v9i2.2513
}

Citation: Koçoğlu, E., \& Sağdıç, M. (2020). Teacher Perceptions on the Use of 5E Learning Cycle Model in Social Studies Courses. Journal of History Culture and Art Research, 9(2), 40-49. doi:http://dx.doi.org/10.7596/taksad.v9i2.2513

\section{Teacher Perceptions on the Use of 5E Learning Cycle Model in Social Studies Courses}

\author{
Erol Koçoğlu ${ }^{1}$
}

Mustafa Sağdıç ${ }^{2}$

\begin{abstract}
Several methods are used to improve meaningful learning levels of students in learning environment during the social studies course learning-instruction process. The $5 \mathrm{E}$ instruction method is among these models. One of the constructivist instructional approaches, the 5E method is an ancillary and regulatory model for teachers who are the leaders in the learning-instruction process. This model, which is significant for teachers, includes a number of stages. Conducting active and effective activities during these stages depends on the organization and transfer of the course activities to the stages of this learning cycle. The aim of the present study was to determine the perceptions of social studies teachers on the use of the $5 \mathrm{E}$ learning cycle method in social studies courses. In the present study that aimed to tackle perceptual analysis with a qualitative approach, the phenomenology design that was deemed adequate for the nature of the study topic was utilized. A semi-structured interview form developed by the authors was used to collect the study data. The study group members, whose perceptions on the research topic were obtained with the semi-structured interview form, included social studies teachers employed in various public middle schools in Malatya province, Turkey. NVivo 11 analysis software was used to assess and analyze the study data based on the sub-themes. The study findings demonstrated that social studies teachers had interesting perceptions on the study topic.
\end{abstract}

Keywords: Social studies, Learning, Learning model, Teacher, 5E learning cycle.

\footnotetext{
1 Doç. Dr., Eğitim Fakültesi, Türkçe ve Sosyal Bilimler Eğitimi Bölümü, İnönü Üniversitesi. E-mail: erol.kocoglu@inonu.edu.tr

2 Doç. Dr., Eğitim Fakültesi, Türkçe ve Sosyal Bilimler Eğitimi Bölümü, Yıldız Teknik Üniversitesi. E-mail: msagdic@yildiz.edu.tr
} 


\section{E Öğrenme Döngüsü Modelinin Sosyal Bilgiler Derslerinde Kullanılmasına illişkin Öğretmen Algıları}

\section{Öz}

Sosyal bilgiler dersi öğrenme-öğretme sürecinde öğrenme ortamında yer alan öğrencilerin anlamlı öğrenme düzeylerini arttırmak amacıyla birçok model kullanılmaktadır. Bu modellerden biri de $5 \mathrm{E}$ modelidir. Yapılandırmacı yaklaşım içerisinde yer alan öğrenme modellerinden biri olan bu model, öğrenme-öğretme sürecinin yürütücüsü olan öğretmenler için bir yardımcı ve düzenleyici modeldir. Öğretmenler için dikkat çekici bir öneme sahip olan bu model, bir takım aşamalardan oluşmaktadır. Bu aşamalardaki etkinliklerin etkili ve anlamlı bir şekilde gerçekleştirilmesi, uygulanan dersin etkinliklerinin bu öğrenme döngüsünün aşamalarına uygun bir şekilde düzenlenip aktarılmasına bağlıdır. Bu ölçütten hareketle yapılan bu araştırmanın amacı, sosyal bilgiler derslerinde 5E öğrenme döngüsü modelinin kullanılmasına ilişkin sosyal bilgiler öğretmenlerinin algılarını belirlemektir. Algısal değerlendirmeyi nitel bir yaklaşımla ele almayı amaçlayan bu araştırmada, araştırma konusunun doğasına uygun olan olgubilim deseni kullanılmıştır. Araştırma bulgularının elde edilmesinde araştırmacılar tarafından hazırlanan yarı yapılandırımış görüşme formu kullanılmıştır. Yarı yapılandırılmış görüşme formu aracılı̆̆ıyla araştırma konusuna ilişkin algılarına başvurulan çalışma grubu üyeleri Malatya il milli eğitim müdürlüğüne bağlı çeşitli ortaokullarda görev yapan sosyal bilgiler öğretmenleri oluşturmaktadır. Araştırma verilerinin alt temalar şeklinde değerlendirilip analiz edilmesinde Nvivo 11 analiz programı kullanıımıştır. Araştırma sonuçlarına bakıldığında, sosyal bilgiler öğretmenlerinin konuya ilişkin dikkat çekici algılara sahip olduğu ortaya çıkmıştır.

Anahtar Kelimler: Sosyal bilgiler, öğrenme, model, öğretmen, 5E öğrenme döngüsü.

\section{Introduction}

The instructional approach that is utilized in education and could be described as philosophical ideas that shape instructional activities could be considered as one of the most important variables in education. Based on the characteristics provided by this variable in educational environment, the approach might lead to variations in the learning-instruction process. Thus, it could be suggested that several historical approaches (theories) were effective in different time periods in the educational selfrealization of human beings throughout the world. Namely, the constructivist approach that has been used since the 2005-2006 academic year in Turkey, is associated with learning not instruction; however, it is centered on the individual in the learning-instruction environment (Aydin and Gungordu, 2015). The constructivist approach, which allows the individuals to establish their own learning limits based on the basic concepts, includes $3 \mathrm{E}, 5 \mathrm{E}$ and $7 \mathrm{E}$ learning cycle models. The learning cycle, which is defined as a strategy in the historical timeline element in the educational process, was developed primarily in the 1960s by Karplus and Thier (1967, cited in IIter and Ünal, 2014) based on the introduction of the concept, implementation of the concept and the discovery of the learning cycle. Since this development of the approach, new modalities have been added by organizing the learning cycle in different fields and by studies conducted by various researchers. These were called 3E, 4E, 5E and 7E methods (Kolb, 1984; Lawson, Abraham and Renner, 1989; Lawson, 1995; Eisenkraft, 2003; Marek, 2008; ilter and Ünal, 2014).

One of the most effective forms of learning cycle based on constructivist learning theory and developed by Bybee, the $5 \mathrm{E}$ model includes skills and activities that increase the individual's interest and curiosity in the learning environment, and keep the individual's attention alive during the learning process and encourage meaningful learning (Bybee, 1997 Anıl and Küçüközer, 2017). Furthermore, it could be argued that the model supports the use of various strategies, methods and techniques, as well as the conceptual formation of the individual in the learning-instruction process (Martin, 2000; Van Hook and Huziak-Clark, 2007; Ürey and Çalık, 2008; Vincent, Cassel and Milligan , 2008; Şahin, Çalık and Çepni, 2009; Yalçın and Bayrakçeken, 2010; Anıl and Küçüközer, 2017). 
The Engage phase includes activities that aim to stimulate students' motivations and curiosity on the topic instructed by the teacher. In this stage, the main objective is to identify the students' prior knowledge on the topic of instruction, to think about the probable solutions to the research problem, and to attract their attention to the course (Morse, Roberts, Szesze \& Wayne, 2004; ilter \& Ünal, 2014). The Explore phase includes activities where students could experiment and observe the topic and test hypotheses associated with the topic. In this stage, through the activities conducted in the learning environment, inadequate learning of the students and their misconceptions on the subject are determined and certain activities are conducted to eliminate these problems. The Explain phase includes activities that allow the students to express and explain the concepts they discovered about the subject. The explanation of the concepts by the students and the development of these concepts based on the suggestions of the teachers, who are the leaders in the learning environment, are among the objectives of this phase. The Elaborate phase includes activities that allow the students to elaborate on the concept or concepts that they explored and explained, expanding these concepts to different environments and cases (Marek \& Cavallo, 2008). The Evaluate phase consists of the analysis of the activities conducted in the previous phases in the learning cycle, conducted by both the teacher and the students. This phase could be conducted at the end of the cycle, or after any cycle phase (Lederman, 2009).

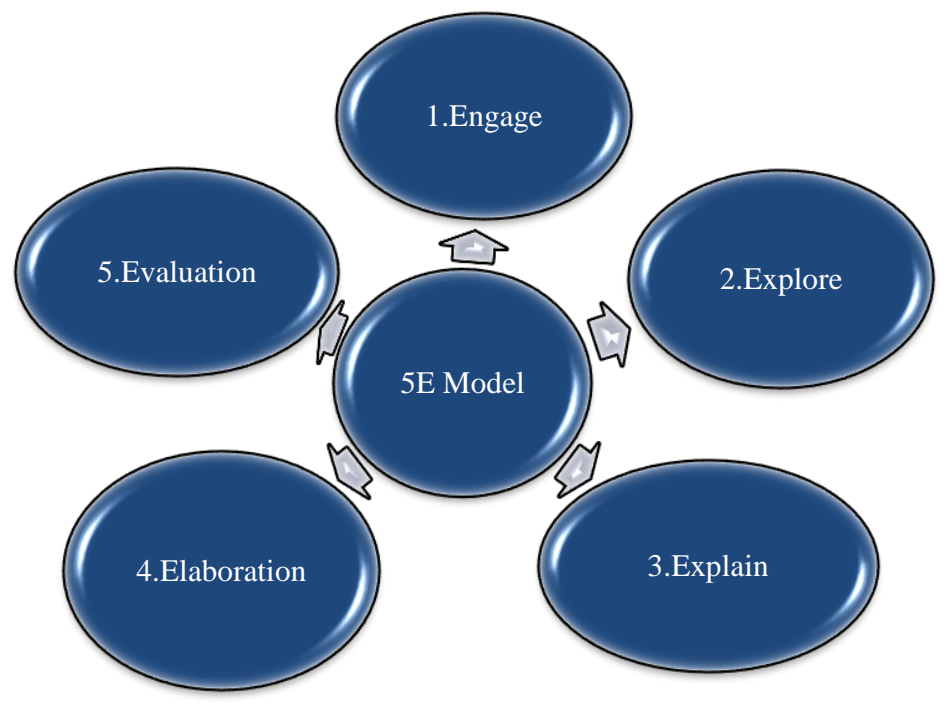

Figure 1. The phases of the $5 \mathrm{E}$ learning cycle model

In the learning environment, the $5 \mathrm{E}$ model, which is based on the individual-centered learning in the learning-instruction process, could be used to increase the meaningful learning levels in the abstract acquisition-based study fields. It could be argued that the social studies education field is suitable for the implementation of all phases of this cycle since it includes multidisciplinary knowledge, skills and values. The implementation of this cycle in social studies education could contribute to the learning of abstract concepts in a concrete and meaningful way towards the achievements included in the field curricula.

\section{The Aim of the Study}

The present study aimed to determine teacher perceptions on the use of $5 \mathrm{E}$ learning cycle method in the social studies course. Based on the main study aim, the following research problems were determined:

$\checkmark$ As a teacher, which concepts you associate with the $5 E$ learning cycle model?

$\checkmark$ Do you consider the use of this model in social studies course adequate and why? 
$\checkmark$ What could be the effects of the use of this model in social studies course on the learning environment?

$\checkmark$ What are your suggestions for the use of this model in social studies course?

\section{Method}

In the research, the qualitative approach was adopted to investigate the subject in depth. Qualitative research is defined as the analysis of a subject or subjects in their natural environment, where the researchers attempt to make sense of and interpret the phenomenon based on the meanings assigned to the phenomenon by individuals (Ekiz, 2003; Doğan, Demir \& Pınar, 2014; Koçoğlu and Egüz, 2019 ). The sub-sections of the study methodology are presented below.

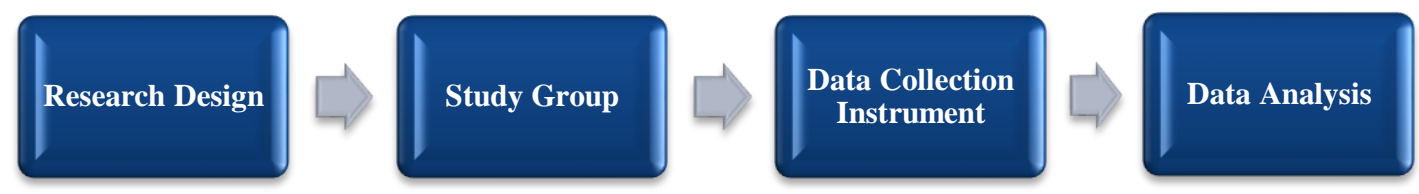

Figure 2. The study methodology

\section{The Research Design}

The present study that aimed to analyze the perceptions of teachers on the use of $5 \mathrm{E}$ learning cycle model in social studies course was carried out with the phenomenology design. This research design was used since phenomenological studies allow in depth investigation of all dimensions of a situation or event and also reveal the perceptions and thoughts of individuals on the research subject (Yıldırım \& Şimşek, 2011).

\section{The Study Group}

The study group included 30 social studies teachers employed in various public schools in Malatya province, Turkey. In the study, purposive sampling method was used to determine the study group members. Thirty teachers who were social sciences education department graduates with the competency to instruct the course were selected by the authors. Each study group member was invited to participate in the research voluntarily, and preliminary information about the study was provided for the volunteering participants. To ensure the privacy of the study group, each member was assigned a moniker such as social studies teacher 1 ...social studies teacher 30 .

\section{Data Collection Instrument}

A semi-structured interview form was developed by the author to determine the perceptions of social studies teachers on the topic of the study, which aimed to determine the teacher perceptions on the use of the $5 \mathrm{E}$ learning cycle method in social studies course after the theoretical framework was established. The interview form questions were initially determined by the author. The interview form was then presented to education field experts at İnönü and Fırat universities to ensure content validity. The interview form was finalized based on the views and recommendations of the field experts. The form included 4 questions.

\section{Data Analysis}

In the present study, which aimed to determine teacher perceptions about the use of $5 \mathrm{E}$ method in social studies course, the data analysis process included the stages of interview, data coding, interpretation and analysis of the sub-themes with the Nvivo11 software. In the study, the data collected with the semi-structured interview form were recorded with a voice recorder and transcribed as Microsoft Word files. After the transcription, the texts were reviewed by the author and then the data were encoded. The line by line analysis approach, proposed by Patton (2002, cited in Doğan, 
Demir, \& Pınar, 2014), was used to describe the views that were directly and explicitly expressed or indirectly implied by the participants. In this context, as the study data were analyzed with the content analysis technique, repeated participant responses were determined and compared, and the categories and themes were determined with the induction method based on these responses. The data were analyzed with computer assistance. NVivo 11 software was used in data analysis and in the model development. Coding was determined with the consensus among authors.

\section{Findings}

The study findings were obtained by thematic analysis of the semi-structured interview form questions.

\section{The Concepts Associated with the 5E Model}

The responses of the study group member social studies teachers to the semi-structured interview form question " As a teacher, which concepts you associate with the 5E learning cycle model?" were analyzed with NVivo 11 software and content analysis technique and the sub-themes are presented in Figure 3. As seen in Figure 3, the perceptions of the study group members revealed the sub-themes of cooperative learning ( $f-5)$, constructivism ( $f-12$ ), active participation ( $f-4)$, transfer ( $f-3$ ) and studentcentered education ( $f-6)$. Based on these findings, it could be suggested that social studies teachers possessed the required theoretical competence on the research subject. A sample statement from the views of the study group members based on the findings presented in Figure 3 is presented below.

"The question you asked about the associations of the $5 E$ model took me back to the years when I was preparing for the exam. Because, I had read and learned this model at that time. I may not remember the entire content, as I did not practice it as a teacher; however, I can say that the conceptual association that it reminded me was the constructivist theory" (Social Studies Teacher, 3).

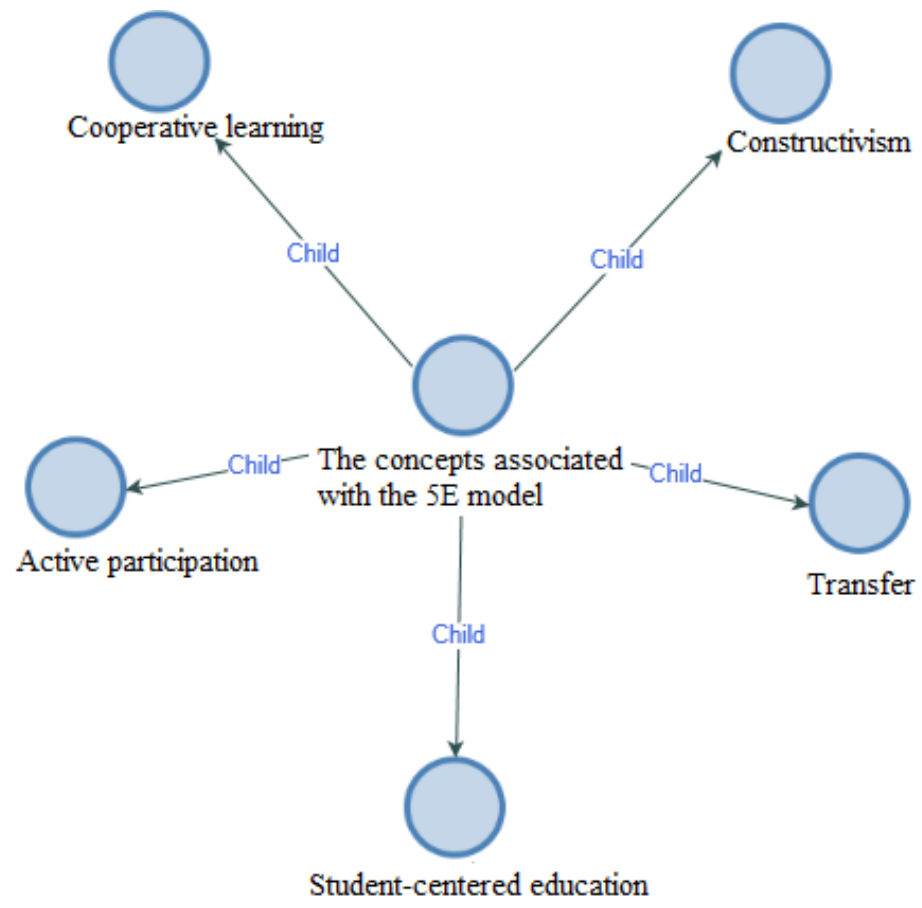

Figure 3. The distribution of the concepts associated with the $5 \mathrm{E}$ model

\section{Adequacy of the Use of 5E Model in Social Studies Course}

The responses of the study group member social studies teachers to the semi-structured interview form question "Do you consider the use of this model in social studies course adequate and why?" 
were analyzed with NVivo 11 software and content analysis technique and the sub-themes are presented in Figure 4.

As seen in Figure 4, it was observed that the social studies teachers in the study group had both positive and negative perceptions about the use of the $5 \mathrm{E}$ model in social studies course. The fact that social studies teachers had different perceptions about the research problems, the findings for which are presented in Figure 4, demonstrated that there was no consensus about the adequacy of the model. The analysis of the findings presented in Figure 3 about the research problem demonstrated that the study group members had different views as presented in sub-themes of "Yes" ( $f-20)$ and "No" ( $f-10)$. The "Yes" theme included the sub-themes of improving meaningful learning ( $f-6)$, increasing motivation ( $f-3)$, acquisition of learning responsibility ( $f-4)$, providing concrete learning ( $f-5)$ and learning by doing ( $f-2)$, and "No" theme included the sub-themes of responsibility of teachers ( $f-4)$, inadequate learning environment ( $f-3)$ and temporal inadequacy ( $f-3)$, and presented in Table 4. Sample statements from the views of the study group members based on the findings presented in Figure 4 are presented below.

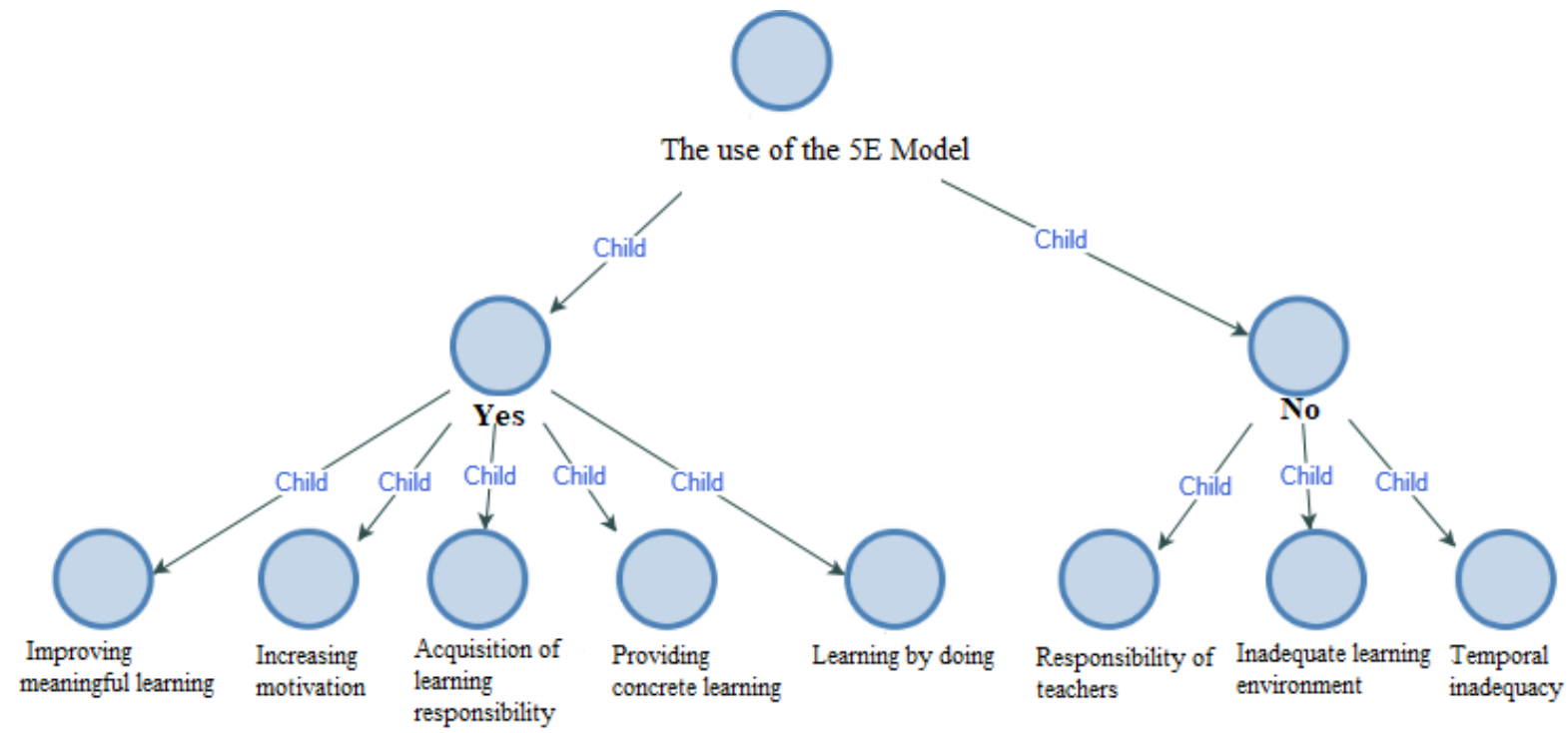

Figure 4. The use of the $5 E$ model in social studies course

"As a social studies teacher, I think it is appropriate to use 5E and similar models in social studies course. Because, I think that such models contribute to meaningful learning by keeping the student's interest in the lesson constantly alive during the process of instruction and learning" (Social Studies Teacher, 7).

"I think it is not appropriate to use the 5E model in social studies course. Because, for such models to work, the teacher should have the required time to interact with the students during the class hours. In short, I think it cannot be applied in a forty minute time period" (Social Studies Teacher, 28).

\section{The Impact of the Use of 5E Model on the Learning Environment}

The responses of the study group member social studies teachers to the semi-structured interview form question "What could be the effects of the use of this model in social studies course on the learning environment?" were analyzed with NVivo 11 software and content analysis technique and the sub-themes are presented in Figure 5. As seen in Figure 5, sub-themes that were determined based on the perceptions of social studies teachers included self-evaluation ( $f-4)$, reduction of the class size ( $f$ $6)$, increasing communication and interaction ( $f-5)$, preventing disciplinary problems ( $f-7)$, one-on-one learning $(f-3)$ and increasing class participation ( $f-5)$. Based on the sub-themes, it could be suggested that the social studies teachers in the study group had different perceptions about the effects of using 
the $5 \mathrm{E}$ model in the learning environment. Sample views of the social studies teachers about this question are presented below.

"The use of models such as $5 E$ in the learning environment where the social studies course is instructed could minimize the possibility of undesired behavior because it would allow the sharing of responsibilities in the learning-instruction process. Disciplinary problems could be minimized since the student who takes the responsibility for the course will be close to stimuli that would lead to negative behavior" (Social Studies Teacher, 29).

\section{Teacher Recommendations on the Use of the 5E Model in Social Studies}

The responses of the study group member social studies teachers to the semi-structured interview form question "What are your suggestions for the use of this model in social studies course?" were analyzed with NVivo 11 software and the findings are presented in Figure 6. The analysis of the findings demonstrated that social studies teachers offered significant suggestions on the use of the $5 \mathrm{E}$ model (Figure 6). It could be suggested that each suggestion was oriented towards effective implementation of the model in the learning-instruction process. The associated suggestions presented as sub-themes in Figure 6 included reduction of the class size (f-4), conducting rubric evaluation (f-5), providing feedback after each model phase ( $f-7)$, organization of activities for the model ( $f-6)$, providing information about the model (f-3), and considering individual differences ( $f-5$ ) (Figure 6). Sample views of the social studies teachers about this question are presented below.

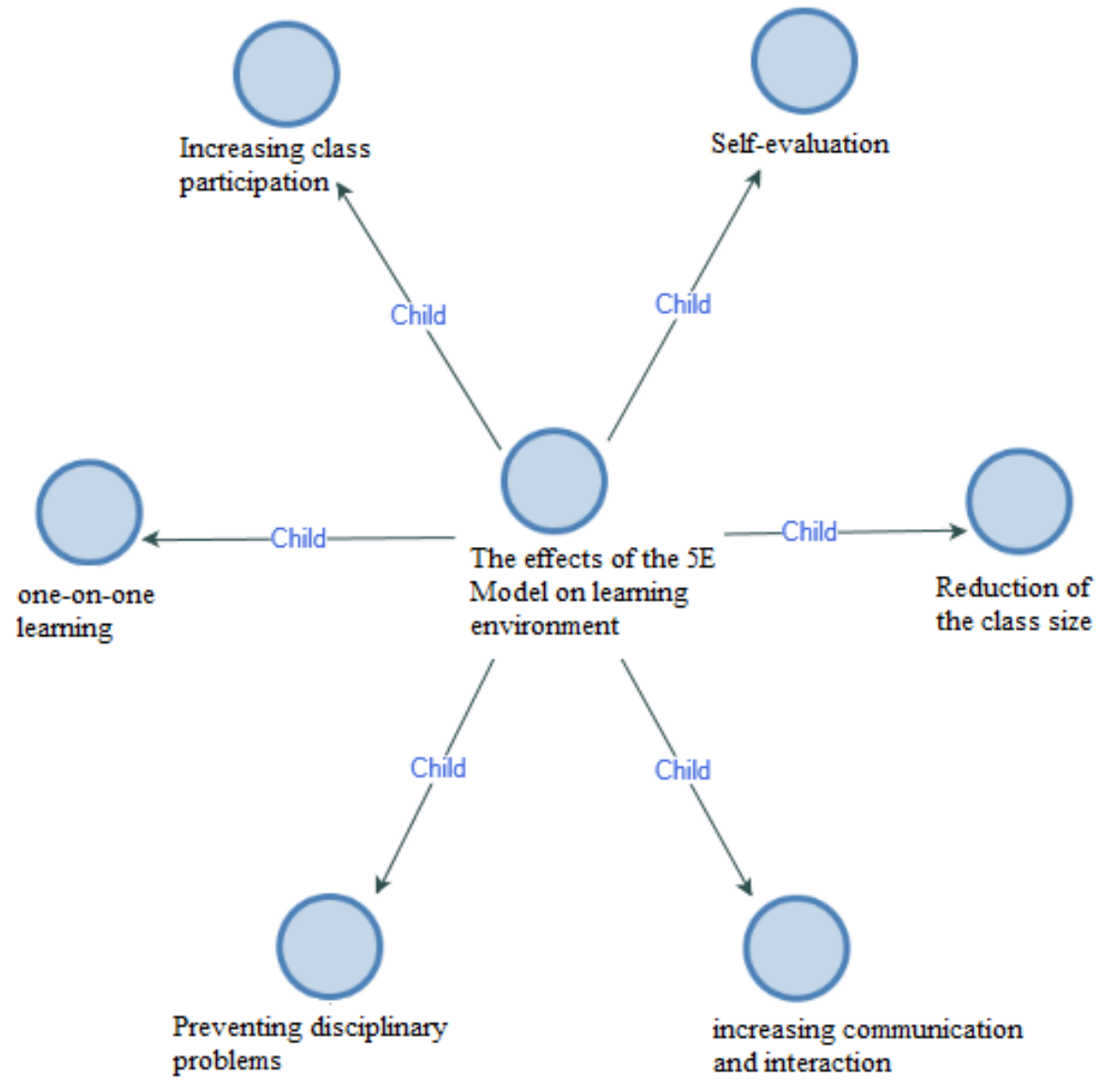

Figure 5. The distribution of the findings on the effects of the $5 \mathrm{E}$ model on learning environment

"I can offer several suggestions on the use of the 5E model in social studies course. However, I would like to express my main suggestion, which could be understood clearly and plainly, since all other suggestions I would offer would be interpreted as a critique of the education system. My suggestion on the use of the model, in which topic you would apply this model in the social studies course, the activities 
associated with that topic should be organized by the teacher based on model phases and then utilized in the learning environment" (Social Studies Teacher, 25).

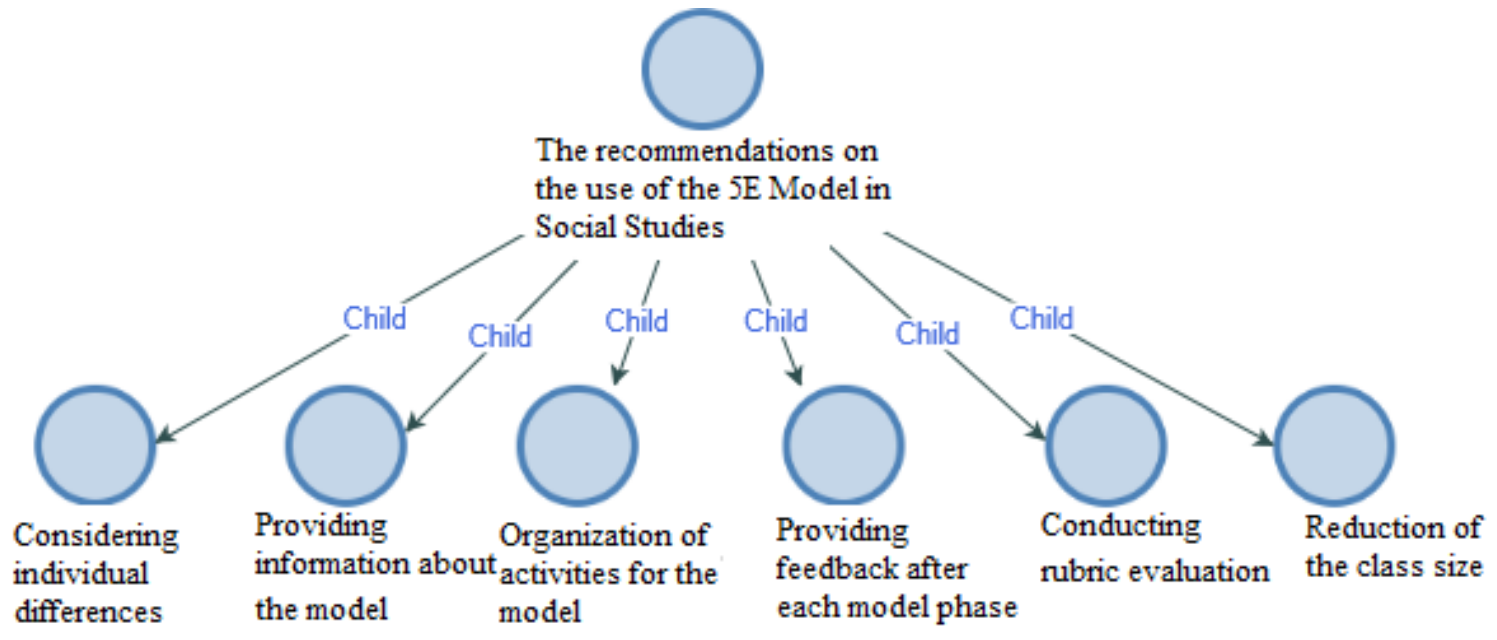

Figure 6. The distribution of the findings on the use of the $5 \mathrm{E}$ model

\section{Conclusion, Discussion and Recommendations}

In the present study, conducted with the phenomenological design using a semi-structured interview form to determine the perceptions of teachers about the use of the $5 \mathrm{E}$ learning cycle model in social studies course, it was observed that different and significant findings were obtained (Figures 3, 4, 5, 6). It could be suggested that the achievement of different results associated with to the research problem was the most important indicator that the social studies teachers included in the study group had different perceptions. The fact that social studies teachers had different perceptions about the study subject could be interpreted as an indication that there was no objective application framework for the use of the $5 \mathrm{E}$ model in social studies education.

One of the several findings obtained in the study was the different conceptual perceptions stated by the social studies teachers. Among these conceptual perceptions, it could be suggested that the most interesting concept was constructivism in the study (Figure 3). The fact that the perceptions of the social studies teachers on the model focused on this concept demonstrated that they had an average competence level in the theoretical framework of the model. Further findings that raised awareness in the study were about the reflections of that competence level on the instruction and learning process in the social studies course. One of these findings revealed that the use of the $5 \mathrm{E}$ learning cycle model in social studies course led to the acquisition of learning responsibility by the learner in the learning environment, in addition to concrete and meaningful learning. This finding was consistent with the findings reported by Hokkanen (2011) that the model increased the interest of the students in the course, as well as increasing meaningful learning levels in the learning-instruction process and the findings reported by Cornelius (2012) that 5E learning cycle model allows students to acquire positive behavior.

Another significant finding obtained in the present study on the $5 E$ model was the effects of the use of the model in social studies course on the learning environment. The perceptions of the social studies teachers, who expressed their views on these effects as sub-themes, revealed that the most important effects of the $5 \mathrm{E}$ model in the social studies course on the learning environment included providing one-on-one learning, improving the communication-interaction in the environment, and student participation (Figure 5). The above-mentioned findings were consistent with the previous study reports that the $5 \mathrm{E}$ model improved the level of participation in the classroom, and developed positive perceptions about the course subject (Blank, 1999; Cherry, 2011; ilter \& Ünal, 2014). It could be 
suggested that the similar findings on the model reported by studies conducted in different time periods were significant for evidencing the importance of the model in the learning-instruction process.

The review of the findings on the suggestions proposed by social studies teachers about the use of $5 \mathrm{E}$ model in social studies course demonstrated that the implementation of the model depended on a number of criteria during the social studies course instruction and learning process. It was observed that these criteria were mostly concerning the teachers, who are the instructors of the course (Figure 6). The foundation of these criteria that are the equivalent of the responsibilities of the teacher during the instruction of the social studies course prescribed by the $5 \mathrm{E}$ model, which is one of the learning cycle models in the constructivist approach, includes meaningful and active learning opportunities for the individual in a learning environment. The suggestions proposed by the teachers in the study group to achieve the above-mentioned goals was a significant finding associated with the uniqueness of the present study. Based on these findings, the following could be recommended:

$\checkmark$ The outcomes of the exemplary application activities in the $5 \mathrm{E}$ model, which is one of the components of the constructivist approach, should be shared comprehensively with social studies teachers.

$\checkmark$ Training on the model content and implementation activities should be provided for social studies teachers by the experts.

$\checkmark$ Social studies teachers should be informed about the reasons for the use of the models that allow the individuals to take responsibility for learning, such as the $5 \mathrm{E}$ model, in social studies courses that are based on abstract achievements.

\section{References}

Anıl, Ö. and Küçüközer, H. (2017). Yapılandırmacı kurama dayalı 5E öğretim modelinde ölçme ve değerlendirme. Kara Harp Okulu Bilim Dergisi, 27(1), 1-24.

Aydın, F. and Güngördü, E. (2015). Coğrafya Eğitiminde Özel Öğretim Yöntemleri. Ankara: PegemAkademi Publications.

Blank, L. M. (1999). A metacognitive learning cycle: A better warranty for student understanding, Science Education, 84, 486-506.

Bybee, R. W. (1997). Achieving Scientific Literacy. N.H.: Heinemann, Portsmouth.

Cherry, G. R. (2011). Analysis of Attitude and Achievement Usıng the 5e Instructional Model in an Interactive Television Environment, ProQuest Digital Doctoral Dissertations, Old Dominion University.

Cornelius, M. (2012). "The 5E Learning Cycle and Students Understanding of the Nature of Science". Unpublished master' thesis Montana State University. Bozeman, Montana.

Doğan, S., Demir, S. B. and Pınar, M. A. (2014). Yönetici görüşlerine göre MEB 2013 Yılı Yönetici Atama ve Yer Değiştirme Yönetmeliği, Kuramsal Eğitimbilim Dergisi, 7(2), 224-245.

Elsenkraft, A. (2003). Expanding the 5E model, The Science Teacher,70(6),56-59.

Ekiz, D. (2003). Eğitimde Araştırma Yöntem ve Metodlarına Giriş. Ankara: Anı Publications.

Hokkanen, S. L. (2011). Improving student achievement, interest and confidence in science through the implementation of the $5 \mathrm{E}$ learning cycle in the middle grades of an urban school. Unpublished master' thesis. Bozeman, Montana Masters of Science, Montana State University. 
illter, ì. and Ünal, Ç. (2014). Sosyal bilgiler öğretiminde 5E öğrenme döngüsü modeline dayalı etkinliklerin öğrenme sürecine etkisi: bir eylem araştırması. TSA, 1, 295-330.

Karplus, R. and Thier, H. D. (1967). A new look at elementary school science. Chicago: Rand- McNally.

Koçoğlu, E. and Egüz, Ş. (2019). Türkiye'de, sosyal bilgiler eğitimine ilişkin alan eğitimcilerinin sorunsal tespitleri. Manas Sosyal Araştırmalar Dergisi, 8(1/1): 27-38

Kolb, D. A. (1984). Experiential learning: Experience as the source of learning and development. Prentice Hall, Englewood Cliffs, NJ.

Lawson, A. E. (1995). Science teaching and development of thinking. Belmont CA USA Wads word.

Lawson, A. E., Abraham, M. R. and Renner, J. W. (1989). A theory of instruction: Using the learning cycle to teach science concepts and thinking skills. Kansas State University, Manhattan, Ks: National Association for research in science teaching.

Lederman, J. S. (2009). "Levels of Inquiry and the 5 E's Learning Cycle Model. Monterey, CA: National Geographic School Publishing" Web: http://www. ngspscience.com, Accessed date: 12 February 2020.

Marek, E. A. (2008). "Why the learning cycle?", Journal of Elementary Science Educating, 20(3), 63-69.

Marek, E. A. and Cavallo, A. M. (2008). The Learning Cycle: Elementary School Science and Beyond. Portsmouth, NH: Heinemann.

Martin, D. J. (2000). Elementary Science Methods: A Constructivist Approach. Belmont, CA: Wadsworth/Thomason Learning.

Morse, G., Roberts, D., Szesze, M. and Wayne, V. (2004). Montgomery Country Public Schools. Science Teacher's Handbook, 36.

Patton, Q. M. (2002). Qualitative evaluation and research methods. London: Sage Publications.

Şahin, C., Çalık, M. and Çepni, S. (2009). Using different conceptual change methods embedded within 5E model: a sample teaching of liquid pressure. Energy Education Science and Technology Part B-Social and Educational Studies, 1 (3-4), 115-125.

Ürey, M. and Çalık, M. (2008). Combining different conceptual change methods within 5E model: a sample teaching design of 'cell'concept and its oxrganelles. In Asia-Pacific Forum on Science Learning and Teaching, 9 (2), 1-15.

Van Hook, S. J. and Huziak-Clark, T. L. (2007). Tip-to-tail: Developing a conceptual model of magnetism with kindergartners using inquiry-based instruction, Journal of Elementary Science Education, 19 (2), 45-58.

Vincent, D., Cassel, D. and Milligan, J. (2008). Will it float?. Science and children, 45 (6), 36.

Yalçın, F. A. and Bayrakçeken, S. (2010). The effect of 5E learning model on preservice science teachers' achievement of acids-bases subject. International Online Journal of Educational Sciences, 2(2), 508531.

Yıldırım, A. and Şimşek, H. (2011). Sosyal bilimlerde nitel araştırma yöntemleri. Ankara: Seçkin Publications. 